\title{
Online financial disclosures in the Nigerian public sector
}

\author{
Edosa Joshua ARONMWAN ${ }^{1)}$; Osariemen ASIRIUWA ${ }^{2)}$
}

1) Department of Accounting, Faculty of Management Sciences, University of Benin, Nigeria

2) Department of Accounting, College of Business and Social Sciences, Covenant University, Nigeria

e-mail correspondence: joshua.aronmwan@uniben.edu

\begin{abstract}
The objective of this study is to examine the online financial disclosure practices by Nigerian public sector entities. In achieving this, the cross-sectional research design was employed and data gathered from 27 states for a one year period. The ordered logistic regression technique was used to estimate the model and the findings reveal that wealth and political competition have significant positive relationships with online financial disclosure in Nigeria while the size of the state has a significant but negative relationship. Also, the age of the state has an insignificant relationship with online financial disclosure in Nigeria. Based on these, the study recommends that healthy competition should be encouraged in forms of public debates, assessment polls on public sector entities, frequent programmes aimed at assessing the progress of public entities probably on a yearly basis or biannual or even at the end of a regime (before the commencement of another).
\end{abstract}

Keywords: Online disclosure, Public sector, Financial disclosure, Political competition, State wealth

\section{INTRODUCTION}

Information plays a crucial role in the activities of any government as well as in the production, preparation, and presentation of reports, although this information has to be first available and accessible by its users. In recent years, due to changing technology and perception, we are experiencing the need for public sector entities to be more transparent in the information they publish and how they relate to citizens (Perez, Hernandez, \& Bolivar, 2007). More so, since the inception of modern financial reporting, financial information has been distributed to its users (shareholder, public and other interested parties) through the use of hard copies (papers) and such reporting may cause delay and impose significant costs of printing and distribution (Jimoh \& Okoye, 2016). However, in this era of information and communication technology, the internet and website have become powerful means that public sector entities can now use to disseminate its information, thereby increasing its transparency, which is part of their policy for good governance. Put differently, the internet offers the possibility of increased interaction between citizens and the government (Chadwick, 2003). In addition, internet reporting has the benefit of low cost, wider reach, high frequency and speed. However, despite these benefits, the practice of internet reporting seems to be poor and varies across companies and across countries (Debrecency, Gray \& Rahman, 2002).

The clamor for transparency in Nigeria is one major cause for more disclosure. 
Nigeria is more-or-less a mono-economy with thirty-six (36) states, each of which is blessed with natural resources. The government also collects taxes from its citizens to provide social amenities as required of them by the constitution. Thus, to aid transparency and accountability of the finances collected, and to ensure maximum utilisation, there is a need for disclosure of both qualitative and quantitative financial information. One way opened for such disclosure is via the internet and websites. However, it has been observed that most developing countries have not keyed into this (Debrecency et al., 2002).

The US, Canada, UK, Ireland, and New Zealand are some countries in which studies on disclosure through the internet have been conducted (Koreto, 1997; Lymer, 1997; Lymer \& Tallberg, 1997; Marston \& Leow, 1998; and Petravick \& Gillett, 1998). The report shows an increasing number on the usage of the internet to disclose information. This shows that internet reporting is already an international practice. In addition, studies have been carried out on online financial disclosures globally, but only a few have been specifically carried out in the area of public sector. Garcia and Garcia (2010); Laswad, Fisher and Oyelere (2005); and Tudor, Blidisel and Popa (2009) are the very few authors that have investigated this in the public sector of various countries. These studies were observed to have been done in New Zealand, Spain, United States, Italy and, Romanian. However, to the best of the researcher's knowledge, very limited researches have been carried out on online financial disclosure in the public sectors of developing and frontier countries like Nigeria.

Although Jimoh and Okoye (2016) did a study on online financial disclosures in Nigeria, their study was limited to a few variables that could be accessed. In this study, however, we improved on the choice of variables and measurements and include political completion as a variable since studies done in the developed countries found it to be a significant determinant of disclosure. To this end, the objective of this study is to examine online financial disclosures in the Nigerian public sector. This study contributes to knowledge and extends the study of Jimoh and Okoye (2016) thereby filling the gap of the paucity of research in Nigeria. To achieve the objective of this study, emphasis is placed on the state governments in Nigeria and is restricted to financial disclosure made online (website) and not in paper form.

The rest of this paper is divided into sections- literature review and hypotheses development (section 2), methodology and model specification (section 3), results and analyses (4), discussion of findings (5), and conclusion and recommendations (6).

\section{LITERATURE REVIEW AND HYPOTHESES DEVELOPMENT}

\section{Concept of disclosure}

According to Hendrickson and Brenda (1992), disclosure is defined as the provision of information needed for the optimal operation of an entity. The general objective of disclosure is to provide information which is necessary to serve the interest of different parties. In considering the amount of information disclosed, entities are expected to be guided by the standards and expectations of regulatory bodies. Therefore, based on this, Hendrickson and Brenda classify the level of disclosure into three types, namely: adequate disclosure, fair disclosure and full disclosure. Adequate disclosure refers to the minimum level of disclosure which is required by regulation to ensure that the financial statement do not mislead its users. Beyond the minimum level of disclosure, we equally have fair disclosure, which is reasonable disclosure based on ethical purpose in order to give equal treatment to all users of the financial statement. That is, disclosures are provided in consideration of the general needs of all users of the 
information. Lastly, we have full disclosure. This deals with providing or disclosing all relevant information. For an entity, the full disclosure principle requires the provision of necessary information so that users can make informed decisions. In other words, the full disclosure principle requires that an entity should include in its financial statements, all information that would affect a user's understanding and decision making. However, this principle is constrained by the cost and benefit analysis of the information being provided.

Furthermore, we have different types of disclosure depending on which classificatory scheme that is employed. According to Chan and Gary (2000), disclosure can be classified based on the medium of communication- hardcopy/paper disclosure or online disclosure. Hardcopy disclosure is the use of paper to disclose information (financial or non-financial) about an entity. It has been the primary means of distributing information to shareholders while online disclosure is disclosing information on the internet or website. With respect to standards or regulations, we can also have mandatory or voluntary disclosure. Mandatory disclosure refers to the minimum disclosure required by the applicable accounting standard; while voluntary disclosure is the disclosure made willingly by an entity without any regulatory requirement or disclosure made beyond the minimum level. Foreclosing on voluntary disclosure, which is the nature of most online reporting, Financial Accounting Standard Boards (FASB, 2001) defines voluntary disclosure as any information rendered that is not overtly required by any standard. Meek, Roberts and Gray (1995) also define voluntary disclosure as the disclosure above the average requirement.

Evidences have been documented on internet financial reporting practices in various countries of the world (Hedlin, 1999; Laswad et al., 2005; and Oyelere, Laswad, \& Fisher, 2003). They all indicate increment in the use of the internet for disclosing financial information. Wickramasinghe and Lichtenstein (2006) assert that extending financial disclosure beyond the traditional production of hard copy financial statements and gaining timeliness in its preparation can be achieved by improving financial information provided on the web through multimedia such as animations, sounds, and/or radios which can equally aid understanding and clarity of such information. However, online disclosure has its cons as Bawaneh (2014) notes that the major challenge of online financial disclosure environment is how to ensure the protection and reliability of the information disclosed on the internet.

\section{Disclosure practices in the Nigerian public sector}

The public sector is expected to promote accountability, transparency, performance, development and service improvement that ensure value for money. However, the Nigerian public service seems to be suffering from a seeming endless illness of which accountability is a major issue. Though Nigeria has three main levels of government, the onus is on the federal government, through the treasury department to prepare the financial statements of the nation, which must show a true and fair view of the state of affairs of the nation at any particular point in time. To this extent, the treasury designed most of the rule and regulation applicable to government accounting. However, as a result of the autonomy given to the state and local government, they are allowed to design for themselves, some of the rules and regulations applicable to each of them. But such rules and regulations must not be in conflict with the federal treasury rules and regulations. Where there is a conflict, the treasury rules and regulations supersede (Adam, 2016).

A study on Nigerian entities was conducted by the World Bank group and it was observed that Nigerian financial reporting practices are deficient (World Bank, 2004). 
Apart from this, studies on disclosure practices in Nigeria were also conducted by Adeyemi (2006), and Ebiringa and Kule (2014) and they also observed that Nigeria's separate reporting practice is weak. However, all these studies were before the adoption of international standards, thus, may not likely be tenable now. In summary, although the practice of full disclosure is not new a concept, it is something that is yet to find its root in our public sector entities, more so, in this period where online reporting is trendy.

\section{Theories on disclosure}

A stakeholder as any person or group of persons who can directly or indirectly influence or be influenced by an organisation, since an entity is created to manage or meet the needs of the stakeholders (Freeman, 1984). Managers of entities are to also perform their duties to stakeholders which may include, but not limited to the host communities, employees, government, public, and suppliers. They should conduct the affairs of the entity in ways that ensure it satisfies all its stakeholders. In addition, managers are to act as agents to ensure the survival of the organisation and safeguard the long term stake of each stakeholder. In the public sector, we can tag the government as the manager while its populace and employees are some of its stakeholders. The government is expected to provide information to stakeholders based on the stakeholders' theory, hence the importance of this theory to this study. This disclosure may equally be presented via the internet.

Capital need theory can be used also to explain disclosure practices. The government aims to get finance to increase its revenue and the capital need theory suggests that disclosure helps in raising capital at a low cost (Choi, 1973). Such disclosure could be online in order for many users to access it.

To finalize on theories of disclosure, legitimacy theory can equally be used. The legitimacy theory assumes that an entity is legitimate when it meets the needs and perceptions of the society at large where it operates (Magness, 2006). Since the legitimacy theory is based on the perception and expectation of the society, entities tend to provide information that would help build a positive perception in the minds of people about them (Cormier \& Gordon, 2001). So the government discloses information about its financial activities to its citizens online in order for them to have a positive perception from the citizen. Though the annual report has been detected as an important source of legitimacy (Dyball, 1998; O'Donovan, 2002), legitimacy through disclosure can also be done online. In conclusion, all these theories support the need for disclosure and provide theoretical bases for this study.

\section{Wealth and online financial disclosure}

Hargittai (1999) opines that economic wealth can be measured using Gross Domestic Product per capita. Countries with a high economic wealth are more transparent in relation to their budgetary information; and better economic performance can be considered essential for e-government development and for implementing online budget disclosure practices (Kim, 2007).

A positive relationship has been found between the level of wealth and the use of e-government in prior studies (Kim, 2007; Lasward et al., 2005). Perez, Bolivar and Hernandez (2008) used wealth as a determinant of government financial report online and concluded that there is a positive association between government financial information reported on the website and economic wealth. Laswad et al. (2005) in their study on the determinants of voluntary internet financial reporting in the public sector, in which municipal wealth was one of the variables, discovered that municipal wealth 
has a positive association with voluntary internet financial reporting in New Zealand. Similarly, Yu (2010) investigated the content accessibility of e-disclosure of financial information in China and also found that wealth is significantly related to the extent of web-based financial reporting. Furthermore, Jimoh and Okoye (2016) conducted a Nigerian study in the public sector using the thirty six states as a sample. State wealth was measured using GDP and the result obtained revealed that state wealth is a significant determinant of voluntary internet financial reporting in the country. In the same vein, Tudor et al. (2009) conducted a study on e-financial reporting within the Romanian public sector using the towns having a population of over 40 thousand inhabitants as the sample. The findings revealed that Romanian local public administrations are positively associated with the revenue of the entities.

All the above findings reveal the following- First; wealth is a significant determinant of internet reporting. Second, it has a positive association with internet reporting thus, the higher the level of wealth, the higher the level of disclosure on the internet. Third, this aligns with the political cost theory. The theory advocates that entities that are profitable or big (either size or wealth) are monitored more than those that are not. Therefore, these would always want to disclose more to prove their legitimacy as well as provide signals to the public that monitors them. To this end, we hypothesise that the wealth of the state has a significant relationship with online financial disclosure in Nigeria (H1).

\section{Size and online financial disclosure}

Some studies (Jimoh \& Okoye, 2016; Laswad et al., 2005) have found size to have a major influence on online financial disclosure and provide benefits such as greater economy of scale cost saving for larger entities, reduced agency cost; information asymmetries between government and the public; and political costs. The reason why large states disclose more information can also be explained by the political cost theory as larger states are expected to be exposed to more public scrutiny compare to smaller states. They therefore tend to disclose more information. Larger states are equally likely to be more complex and complexity demands more disclosure.

We also find that the results obtained from various studies have been positive (Cinca, Mar, \& Pilar, 2008; Debreceny et al., 2002; and Yu, 2010). Laswad et al. (2005) examined online financial disclosure using size as one of their variable and the result obtained was positive. One reason documented for their finding is that the citizens living in large municipalities or states which are far from the capital will rely more on the internet to get information resulting in a more intense demand for online reporting in large states (Laswad et al., 2005). Furthermore, large states can have a reduction in cost when it supplies its financial information through the website compared to smaller states because they can have skilled staff that can develop for them a website and also keep it updated. Large firms are also sensitive to political cost and will disclose more in order to reduce public criticisms or monitoring of their affairs.

Serrano-Cinca, Rueda-Tomas and Portillo-Tarragona (2009) also investigated the web-based disclosures by local public administrations. Their findings showed that Spanish L.G.A characterised with large state, facilitate online financial disclosure. Garcia and Garcia (2010) used two regression models to test the hypothesis relating voluntary financial e-disclosure and some determinants which included size. They found a positive relationship between size and reporting financial information through websites. Style and Tennyson (2007) also carried out a similar study, but in the US. Size was included as a variable and the finding was positive. Groff and Pitman (2004) investigated on the same reporting medium, but used cities instead of local government 
areas as the sample; the finding therefrom supported prior studies. However, Robbins and Austin (1986) included size as a variable and concluded that a non-positive relationship existed between size and internet reporting. In summary, prior researches indicate that size is one of the factors most associated with the disclosure of information through the internet. Thus, we hypothesise that the size of the state has a significant relationship with online financial disclosure in Nigeria (H2).

\section{Age and online financial disclosure}

Age here refers to the year of incorporation or creation of an entity. According to the organisation life cycle theory, an entity grows in stages and its performance and operations are affected by each stage (Daft, 2008). Similarly, based on Levinson's theory (season of life), there are stages that an individual passes through to become an adult and with each stage, associated responsibilities abound (Levinson, 1986). Trying to apply this, disclosure is a responsibility of entities to their stakeholders and just as the entities increase (numerically or financially), casual empiric make us predict based on reputation risk that the entities become matured (responsible) and avoid risky behavior. Thus, although the government does not die, we expect that as it continues, it becomes more mature (responsible) and if disclosure is a responsibility of any entity to its stakeholders, the government should also disclose more based on its duration of existence (age). Bank, Fisher and Nelson (1997) in their study showed that established universities tended to have better quality disclosure than new universities in the categories of service performance and financial performance, therefore, suggesting a positive relationship between age and disclosure. Flowing from these, we expect that the age of the state in Nigeria has a significant relationship with online financial disclosure (H3).

\section{Political competition and online financial disclosure}

Studies that have investigated the extent of competition on the political scene as a determinant of online financial disclosure include Laswad et al. (2005) who examined voluntary reporting and the degree of political competition in New Zealand local government. They concluded that there is a positive relationship between the political competition and online reporting of financial information. They equally noted that if there is an opposition group to serve as watchdog against the government, the latter will have no choice than to be responsible (includes disclosure \& accountability) as these opposition groups will orient the electorate on any deviant behaviour. Gandia and Archidona (2008) examined the websites of large Spanish city councils in order to assess the extent of information disseminated on the internet and determine what factors affect information disclosure level. Political competition was one of the determinants used and the result showed that political competition has a significant positive relationship with disclosure level. Similarly, Cinca et al. (2008) examined the determinants of voluntary internet financial reporting (e-disclosure), diverse political aspect was included as one of the determinants used and the result showed that political competition significantly influence e-disclosure.

Furthermore, Tudor et al. (2009) in their study found that stiffer political competition leads to more supply of information by political manager. By extension, Serrano-Cinca et al. (2009) findings on e-disclosure by local public administration showed that political aspect has a positive influence on voluntary internet financial reporting. Equally, Garcia (2010) investigated political competition vis-a-vis voluntary financial e-disclosure and found out that political competition significantly influences the likelihood of reporting financial information through websites. Based on this, we 
hypothesise that political competition has a significant relationship with online financial disclosure in Nigeria (H4).

\section{METHODOLOGY AND MODEL SPECIFICATION}

For the purpose of this research, the cross-sectional design is used because the study examines disclosure across states (cross section) for a particular point in time (2016). The population of interest in this study is the thirty-six state governments in Nigeria. Due to the small number of states, the study was based on a census rather than a sample. Thus, the entire population should be same as the sample. However, in the course of the study, we found that some states do not have websites and some that had, were experiencing technical challenges. These were therefore removed from the sample. In summary, the target population and sample consists of 27 states that have operational websites. The data for this research was from secondary sources. It includes the: 2012 Nigeria Bureau of statistic report and other information present on its website, as well as the websites of all the sampled states.

In order to measure online financial disclosure, a weighed disclosure index was used. This weighted disclosure checklist was adapted from Laswad et al. (2005) A content analysis of the website was done and if the website has no budget or financial related disclosure, we assign 0 , if it has just a budget highlight, we assign the value 1 . If it has a full budget report, we assign the value 2 and if it has both budget report and financial statement, we assign the value 3 . Therefore the maximum a state may have is 3 while the minimum is zero (no disclosure). Despite these, a major limitation was in accessing the data especially the GDP for the proposed year thus, to circumvent this, the year (2012) which was available, accessible and had complete information on the states was used.

\section{Model specifications}

Jimoh and Okoye (2016) conducted an indigenous study to investigate the nature of voluntary internet financial disclosure. The model below was used in their study:

$\mathrm{WRP}=\mathrm{a}_{0}+\mathrm{a}_{1}$ POP $+\mathrm{a}_{2}$ AGE $+\mathrm{a}_{3}$ GDP $+\mathrm{a}_{4}$ INTL $+\mathrm{e}$

Where $\mathrm{WRP}=$ Website reporting; $\mathrm{POP}=$ Population; $\mathrm{AGE}=$ Age of state; $\mathrm{GDP}=$ Wealth of state; and INTL= International transport.

In order to extend the study, improve on the model and fit it for this study, we adapted the above model. Thus the model specification of this study is stated below:

$\mathrm{OFD}_{1}=\beta_{\mathrm{o}}+\beta_{1} \mathrm{WEALTH}_{\mathrm{i}}+\beta_{2} \mathrm{SIZE}_{\mathrm{i}}+\beta_{3} \mathrm{AGE}_{\mathrm{i}}+\beta_{4} \mathrm{PC}_{\mathrm{i}}+\tau$.

Where $\mathrm{OFD}=$ online financial reporting of $\mathrm{i}$ state; WEALTH= wealth of $\mathrm{i}$ state; $\mathrm{SIZE}=$ size of i state; $\mathrm{AGE}=$ age of $\mathrm{i}$ state; $\mathrm{PC}=$ political competition in i state; $\beta 0=$ intercept; $\beta 1, \beta 2, \beta 3, \beta 4=$ parameter estimate. Aprior expectations are that $\beta 1, \beta 2, \beta 3, \beta 4>0$

A summary of the measurement of the variables is found in Table 1. 
Table 1. Measurement and proxy

\begin{tabular}{llllc}
\hline Variable & Proxy & Measurement & Source & $\begin{array}{l}\text { Apriori } \\
\text { sign }\end{array}$ \\
\hline $\begin{array}{l}\text { Online financial } \\
\text { disclosure }\end{array}$ & OFD & Weighted disclosure index & $\begin{array}{l}\text { Laswad et al. } \\
(2005)\end{array}$ & \\
\hline Wealth & Wealth & GDP per capita & $\begin{array}{l}\text { Jimoh and Okoye } \\
(2016)\end{array}$ & + \\
\hline Size & Size & $\begin{array}{l}\text { Internally Generated } \\
\text { Revenue (IGR) }\end{array}$ & Tudor et al. (2009) & + \\
\hline Age & Age & $\begin{array}{l}\text { 2016 less year of creation } \\
\text { of each state }\end{array}$ & $\begin{array}{l}\text { Jimoh and Okoye } \\
(2016)\end{array}$ & + \\
\hline $\begin{array}{l}\text { Political } \\
\text { competition }\end{array}$ & PC & $\begin{array}{l}\text { If governor elect is not } \\
\text { from the same party with } \\
\text { the ruling party the value 1 } \\
\text { is used if otherwise, 0 is } \\
\text { used }\end{array}$ & Tudor et al. (2009) & + \\
& \multicolumn{3}{l}{} & \\
\hline Source: Researcher compilation (2018) &
\end{tabular}

To estimate the model, the ordered logistic regression technique was used. The choice of this technique is due to the ordered nature of the dependent variable. In addition, descriptive statistics and correlation analyses were also be presented.

\section{RESULTS AND ANALYSIS}

\section{Descriptive analysis}

This section provides summary statistics on the measures of central tendency (mean, median), measure of dispersion (standard deviation) and normality of distribution (Jarque-Bera statistics). The essence is to help describe the nature of the data.

Table 2. Descriptive statistics

\begin{tabular}{lrrrrr}
\hline & OFD & WEALTH & PC & AGE & SIZE \\
\hline Mean & 0.925926 & $8.55 \mathrm{E}-08$ & 0.333333 & 31.48148 & 25.66000 \\
Median & 1.000000 & $4.83 \mathrm{E}-08$ & 0.000000 & 25.00000 & 8.960000 \\
Maximum & 3.000000 & $5.94 \mathrm{E}-07$ & 1.000000 & 49.00000 & 301.1900 \\
Minimum & 0.000000 & $4.44 \mathrm{E}-09$ & 0.000000 & 20.00000 & 2.090000 \\
Std. Dev. & 0.997147 & $1.16 \mathrm{E}-07$ & 0.480384 & 9.904818 & 57.96187 \\
\hline Skewness & 0.385664 & 3.384175 & 0.707107 & 0.444717 & 4.226746 \\
Kurtosis & 1.617561 & 15.12638 & 1.500000 & 1.774193 & 20.44390 \\
\hline Jarque-Bera & 2.819345 & 216.9671 & 4.781250 & 2.580408 & 422.7200 \\
Probability & 0.244223 & 0.000000 & 0.091572 & 0.275215 & 0.000000 \\
\hline Sum & 25.00000 & $2.31 \mathrm{E}-06$ & 9.000000 & 850.0000 & 692.8200 \\
Sum Sq. Dev. & 25.85185 & $3.48 \mathrm{E}-13$ & 6.000000 & 2550.741 & 87349.04 \\
\hline Observations & 27 & 27 & 27 & 27 & 27 \\
\hline Sourc: Evitur
\end{tabular}

Source: Eviews 7.0

Table 2 above provides information that helps to describe the characteristics of the variables used in this study. With emphasis on the dependent variable (online financial disclosure; OFD), the mean is 0.925926 and approximates the median (1). This reveals that most states provide just budget highlights as against other in-depth disclosures (full budgets and/ financial statements). In addition, the skewness is 
0.385664 indicating that the values for OFD are aligned towards the right. The JB statistics of 2.819345 and p-value of 0.244223 reveal that the values for OFD are not normally distributed.

Looking at other variables, it can be observed that the values for WEALTH, PC and SIZE are normally distributed at $5 \%$ and $10 \%$ significance levels. From the maximum and minimum values of AGE, we see that the oldest state has been in existence for 49 years while the youngest is about 25 years of age.

\section{Correlation analysis}

Still on descriptive statistics, the correlation matrix as presented in table 3 shows the extent of association between the dependent variables and other variables. As expected, the correlation between a variable and itself is unitary. Furthermore, the table 3 shows that the association between OFD and WEALTH is weak based on a correlation coefficient of -0.006615 ; between OFD and PC is fair based on a correlation coefficient of 0.214115 ; between OFD and AGE is equally fair based on a correlation coefficient of 0.210432; and between OFD and SIZE is also fair based on a correlation coefficient of 0.212629 .

Table 3. Correlation matrix

\begin{tabular}{|c|c|c|c|c|c|}
\hline \multicolumn{6}{|l|}{ Correlation } \\
\hline \multicolumn{6}{|l|}{ t-Statistic } \\
\hline Probability & OFD & WEALTH & $\mathrm{PC}$ & AGE & SIZE \\
\hline \multirow[t]{3}{*}{$\overline{\text { OFD }}$} & 1.000000 & & & & \\
\hline & ----- & & & & \\
\hline & ----- & & & & \\
\hline \multirow[t]{3}{*}{ WEALTH } & -0.006615 & 1.000000 & & & \\
\hline & -0.033076 & ----- & & & \\
\hline & 0.9739 & ----- & & & \\
\hline \multirow[t]{3}{*}{$\overline{\mathrm{PC}}$} & 0.214115 & -0.013247 & 1.000000 & & \\
\hline & 1.095993 & -0.066240 & ----- & & \\
\hline & 0.2835 & 0.9477 & ----- & & \\
\hline \multirow[t]{3}{*}{$\overline{\mathrm{AGE}}$} & -0.210432 & 0.354125 & -0.366445 & 1.000000 & \\
\hline & -1.076261 & 1.893318 & -1.969204 & ----- & \\
\hline & 0.2921 & 0.0699 & 0.0601 & ----- & \\
\hline \multirow[t]{3}{*}{$\overline{\text { SIZE }}$} & -0.212629 & 0.931110 & -0.035528 & 0.453602 & 1.000000 \\
\hline & -1.088027 & 12.76410 & -0.177750 & 2.544879 & ----- \\
\hline & 0.2870 & 0.0000 & 0.8604 & 0.0175 & ----- \\
\hline
\end{tabular}

Source: Eviews 7.0

Going on to the association amongst the independent variables, we observe that the strongest association is between SIZE and WEALTH while the weakest is between PC and WEALTH. Furthermore, aside the association between SIZE and WEALTH, other coefficients are lower than 0.50 , thus, the presence of multicollinearity amongst the variables is unlikely.

\section{Regression analysis}

To test for the significance of the causal relationship between the dependent and independent variables, an ordered regression technique has been employed. The choice of this technique is due to the ordered nature of the dependent variable which allows it fall within zero (0) and three (3). 
Table 4. Estimation output

\begin{tabular}{lllll}
\hline \hline Variable & Coefficient & Std. Error & z-Statistic & Prob. \\
\hline \hline WEALTH & 25921037 & 9436046. & 2.747023 & 0.0060 \\
PC & 1.329150 & 0.678094 & 1.960126 & 0.0500 \\
AGE & 0.039973 & 0.042658 & 0.937065 & 0.3487 \\
SIZE & -0.086107 & 0.036349 & -2.368893 & 0.0178 \\
\hline & Limit Points & & & \\
\hline LIMIT_1:C(5) & 1.959340 & 1.347399 & 1.454165 & 0.1459 \\
LIMIT_2:C(6) & 2.485166 & 1.439032 & 1.726971 & 0.0842 \\
LIMIT_3:C(7) & 5.046358 & 1.911793 & 2.639594 & 0.0083 \\
\hline \hline Pseudo R-squared & 0.268372 & Akaike info criterion & 2.161867 \\
Schwarz criterion & 2.497825 & Log likelihood & -22.18521 \\
Hannan-Quinn criter. & 2.261765 & Restr. log likelihood & -30.32306 \\
LR statistic & 16.27570 & Avg. log likelihood & -0.821674 \\
Prob(LR statistic) & 0.002671 & & & \\
\hline \hline
\end{tabular}

Source: Eviews 7.0

The pseudo R-squared is 0.268372 as seen in Table 4 . This indicates that the independent variables jointly explain $26.8 \%$ of the systemic variation in the dependent variable. The LR statistics of 16.27570 and associated p-value of 0.002671 reveal that the model has a sound predictive power and can be used for policy making. It also reveals that the relationship between the dependent variable and independent variable is linear and predicted by a probability distribution.

Based on the individual z-statistics, we found that three of the independent variables have significant relationships with the dependent variable. Specifically, WEALTH has a z-statistics of 2.747023 ( $\mathrm{p}$-value $<0.05$ ) indicating that wealthy states engage in more online financial disclosure. Therefore, at $5 \%$ significance level, we fail to accept the null hypothesis that there is no significant relationship between wealth and online financial disclosure. Second, PC has a z-statistics of 1.960126 ( $p$-value $<0.05$ ). This shows that that the extent of political competition significantly and positively relates to online financial disclosure. It also indicates that the more the political competition, the more the disclosure. Therefore, at 5\% significance level, we also fail to accept the null hypothesis that there is no significant relationship between political competition and online financial disclosure. Third, AGE has a z-statistics of 0.937065 $(\mathrm{P}-$ Value $>0.05)$ which indicates that the age of the state has a positive relationship with online financial disclosure although the relationship is insignificant. In this regards, we accept the null hypothesis of an insignificant relationship between the age of the state and online financial disclosure. Fourth, table 4 reveals that SIZE has a z-statistics of 2.368893. The associated $p$-value is 0.0178 and lower than $5 \%$, thus, leading to the conclusion that SIZE is significant, and negatively related to online financial disclosure. Therefore, this leads us to accept the alternative hypothesis and reject the null hypothesis that there is no significant relationship between the size of a state and online financial disclosure.

\section{DISCUSSION OF FINDINGS}

First, the study found that wealth has a significant and positive relationship with online financial disclosure. The implication of this finding is that wealthier states tend to 
disclose more financial information for the public and one way they do it is via the website. This finding aligns with the popular findings in this area and supports the findings of earlier researchers like Jimoh and Okoye (2016), Yu (2010) and Laswad et al. (2005). This finding is as predicted by the political cost theory. The theory advocates that entities that are profitable or big (either size or wealth) are monitored more than those that are not. Therefore, these would always want to disclose more to proof legitimacy as well as provide signals to the public that monitors them.

Second, this study reveals that size has a negative and significant relationship with online financial disclosure. This means that smaller states disclosure more than larger states. This finding negates popular findings in this area and contradicts the findings of $\mathrm{Yu}$ (2010), Garcia and Garcia (2010) and Style and Tennyson (2007). In addition, this finding negates the prediction of the political cost theory and tends to align with political power theory wherein size is associated with power and those that have large size tend to exert control and influence which may be a reason while larger states do not disclose more information online knowing well that they may be able to control any negative outcome therefrom.

Third is the hypothesis on age and online financial disclosure. From table 4, we see that there is no significant relationship between age and online financial disclosure at $5 \%$ level of significance. This finding does not support our earlier prediction that as a state grows (become more matured and responsible), its disclosure responsibility to stakeholders should increase based on its duration of existence. However, it complements the finding of Jimoh and Okoye (2016).

Fourth, the table 4 reveals that political competition (PC) is significantly and positively related to online financial disclosure. It also indicates that the more the political competition, the more the disclosure. This finding aligns with the popular finding in this area such as Tudor et al (2009), Garcia and Garcia (2010) and Laswad et al. (2005). A plausible explanation for this finding is that if there is an opposition group to serve as watchdog against the government, the latter will have no choice than to be responsible (includes disclosure \& accountability) because these opposition groups can orient the electorate on any deviant behaviour thereby dethroning the present government in a succeeding regime. For this cause, it is expected that increase in political competition should be accompanied by increased disclosures.

\section{CONCLUSIONS, RECOMMENDATIONS AND LIMITATIONS}

\section{Conclusion}

Flowing from the preceding sections, we reemphasize that the objective of this study was to investigate online financial disclosures in the Nigerian public sector. This study contributes to knowledge by improving on the methodology as used by Jimoh and Okoye (2016), concluding that the online financial disclosure practice is quite weak and wealth, size and political competition are significant determinants of the nature of online financial disclosure in the Nigerian public sector.

\section{Recommendations}

Based on above findings, the study recommends that since political competition is observed to be a significant and positive determinant of online financial disclosure, healthy competition should be encouraged in forms of public debates, assessment polls on public sector entities, frequent programmes aimed at assessing the progress of public entities probably on a yearly basis or biannual or even at the end of a regime (before the 
commencement of another). Also, further studies should be carried out using other tiers of government or forms of public sector entities.

\section{Limitation of study}

This study employed a cross-sectional research design that focused on just one year period across twenty-seven (27) states, based on availability of data. Due to the peculiarity of each state, the findings therefrom should be interpreted with caution. In addition, further studies may need to increase the time frame to allow for more robust findings.

\section{REFERENCES}

Adams, R. A. (2016). Public Sector Accounting and Finance made simple. Nigeria: Lagos, Corporate publisher ventures.

Adeyemi, S. B. (2006). Impact of Accounting Standards on Financial Reporting in Nigeria. Unpublished Ph.D Thesis, University of Lagos.

Banks, W., Fisher, J., \& Nelson, M. (1997). University accountability in England, Wales and Northern Ireland: 1992-1994. Journal of International Accounting, Auditing and Taxation, 6(2), 211-227.

Bawaneh, S. S. (2014). Information security for organizations and accounting information systems: A Jordan banking sector case. International Review of Management and Business Research, 3(2), 1174-1188

Chadwick, A. (2003). Bringing e-democracy back in why it matters for future research on e-governance. Social Science Computer Review, l21(14), 443-445.

Chan, G. K., \& Gray, S. J. (2002). Ownership structure and corporate voluntary in Singapore. International Journal of Accounting, 37, 247-265

Choi, F. D. S. (1973). Financial disclosure and entry to the European capital market. Journal of Accounting Research, 11(22), 159-175.

Cinca, S., Mar, R. T., \& Pilar, P. T. (2008). Factors influencing e-disclosure in local public administrations. Document de Trabajo -03, facultad de ciencias economicas.

Cornier, D., \& Garden, I. (2001). An examination of social and environmental reporting strategies. Accounting, Auditing and Accountability Journal, 14(5), 587-616.

Daft, R. L. (2008). Organizational Theory and Design $\left(10^{\text {th }} \mathrm{ed}\right)$. USA, South-Western, Cengage Learning

Debreceny, R., Gray, G. L., \& Rahman, A. (2002). The determinant of internet of financial reporting. Journal of Accounting and Public policy, 21(4-5), 371.394.

Dyball, M. (1998). Corporate annual report as promotional tools: The case of Australian National Industries Limited. Asian Review of Accounting, 6(2), 25-53.

Ebiringa, T. O., \& Kule, L. (2014). Offsharing for sustainable value management. Serbian Journal of Management, 9(1), 105-119.

Financial Accounting Standard Board (FASB, 2001). Improving business reporting: Insight into enhancing voluntary disclosure- steering committee report. Business Reporting Research Project. FASB, Washington D.C

Freeman, R. E. (1984). Strategic management: A stakeholders approach. Bostan M.A. Pitman

Gandia, J. L., \& Archidona, M. C. (2008). Determinant of website information by Spanish GN council. Online information Review, 32(1), 35-57.

Garcia, A. C., \& Garcia, J. (2010). Determinant of online reporting of accounting information by Spanish L.G.A. Local Government Studies, 36(5), 679-695. 
Groff, J. E., \& Pitman, M. K. (2004). Municipal financial reporting on the World Wide Web. Journal of Government Financial Management, 53(2), 20-26

Hargittai, E. (1999). Weaving the Western web: Explaining differences in internet connectivity among OECD countries. Telecommunication Policy, 23(10-11), 701-718

Healy, P. M., \& Palpu, K. G. (2001). Information asymmetry, corporate disclosure and the capital markets: A Review of the empirical disclosure literature. Journal of Accounting and Economics, 31(1/3), 405 - 440.

Hedlin, P. (1999). The internet as a vehicle for investor relations: The Swedish case. The European Accounting Review, 8(2), 373-381

Hendrickson, E. S., \& Brenda, M. F. (1992). Accounting Theory (5 $\left.5^{\text {th }} \mathrm{ed}\right)$. London: Richard Irwin

Jimoh, J. \& Okoye, A. O. (2016). Voluntary internal financial reporting in the Nigerian public sector Igbinedion University Journal of Accounting, 12,40-61, 2016

Kim, C. (2007). A gross national analysis of global e-government. Public Organizational Review, 7(1), 317 -329

Koreto, R. J. (1997). When the bottom line is online. Journal of Accountancy, 183(3) 63-65

Laswad, F., Fisher, R., \& Oyelere, P. (2005). Determinant of voluntary internet financial reporting by local government authorities. Journal of Accountability and Public Policy, 24(2), 101-121

Levinson, D. J. (1986). A conception of adult development. American Psychologist, 41(1), 3-13.

Lymer, A. (1997). Corporate reporting via internet: A survey of current usage in the UK and discussion of issues. First Financial Reporting and Business communication Conference, Cardiff.

Lymer, A., \& Tallberg, A. (1997). Corporate reporting and the internet: A Survey and commentary on the use of the WWW in corporate reporting in the UK and Finland. Paper presented at the Annual Congress of the European Accounting Association, Graz, Austria.

Magness, V. (2006). Strategic posture, financial performance and environmental disclosure: An empirical test of legitimacy theory. Accounting, Auditing \& Accountability Journal, 19, 540-563.

Marston, C. \& Leow, C. Y. (1998). Financial reporting on the internet by leading UK companies. Paper presented at the 21st Annual Congress of the European Accounting Association, Antwerp, Belgium.

Meet, G. K., Roberts, C. B., \& Gray, S. J. (1995). Factors influencing voluntary annual report disclosures by US., UK. and continental European Multinational corporations. Journal of International Business Studies, 555-572

O'Donovan, G. (2002). Environmental disclosures in annual report: Extending the applicability and predictive power of legitimacy theory. Accounting, Auditing and Accountability Journal, 15(3), 344-371

Oyelere, P., Laswad, F., \& Fisher, R. (2003). Determinants of internet financial reporting by New Zealand companies. Journal of International Financial Management and Accounting, 14(1), 26-63.

Perez, C., Bolivar, M. P. R. \& Hernandez, L.A.M. (2008). E-Government process and incentives for online public financial information. Journal: Online Information Review, 32(3), $379-400$ 
Perez, C., Hernandez, L. A. M. \& Bolívar, M. P. R. (2007). Citizens' access to on-line governmental financial information: Practices in the European Union countries. The American Review of Public Administration, 37(2),142-177.

Petravick, S. \& Gillett, J. W. (1998). Distributing earnings reports on the internet. Management Accounting, 80(4), 26-29.

Robbins, W. A., \& Austin, K. R. (1986). Disclosure quality in governmental financial reports: An assessment of the appropriateness of a compound measure. Journal of Accounting Research, 24(2), 412-421.

Serrano-Cinca, C., Rueda-Tomas, M., \& Portillo-Tarragona, P. (2009). Factors influencing e-disclosure in local public administrations: Environment and Planning. Government \& Policy, 27(2), 355-378.

Styles, A. K., \& Tennyson, M. (2007). The accessibility of financial reporting of U.S. municipalities on the internet. Journal of Public Budgeting, Accounting and Financial Management, 19(1), 56-92.

Tudor, A. T., Blidisel, R., \& Popa, A. (2009). E-Financial reporting within the Romanian public sector governance. Paper presented in Conference on eGovernment at Westminster Business School University of Westminster London. 628-637

Wickramasinghe, N., \& Lichtenstein, S. (2006). Supporting knowledge creation with Email. International Journal of Innovation and Learning, 3(4), 416-426.

World Bank (2004). Nigeria-Report on the Observance of Standards and Codes (ROSC): Accounting and auditing. Washington DC: Author

$\mathrm{Yu}, \mathrm{H}$. (2010). The determinants of internet based disclosure of government financial information. Conference proceeding of Management and Service Science. 